\title{
Pelagibaca bermudensis gen. nov., sp. nov., a novel marine bacterium within the Roseobacter clade in the order Rhodobacterales
}

\author{
Jang-Cheon Cho $^{1}$ and Stephen J. Giovannoni ${ }^{2}$ \\ ${ }^{1}$ Division of Life and Marine Sciences, Inha University, Incheon 402-751, Republic of Korea \\ ${ }^{2}$ Department of Microbiology, Oregon State University, Corvallis, OR 97331, USA
}

Jang-Cheon Cho

chojc@inha.ac.kr

\begin{abstract}
A Gram-negative, chemoheterotrophic, facultatively anaerobic, slightly halophilic, oval-shaped marine bacterium, designated $\mathrm{HTCC} 2601^{\top}$, was isolated from the western Sargasso Sea by high-throughput culturing involving dilution to extinction. Although the 16S rRNA gene sequence similarity between the isolate and Salipiger mucosus was $96.5 \%$, phylogenetic analyses using different treeing algorithms clearly indicated that the strain forms a distinct lineage within a clade containing the recently classified genera Salipiger and Palleronia in the order Rhodobacterales of the Alphaproteobacteria. The DNA-DNA relatedness between strain $\mathrm{HTCC} 2601^{\top}$ and S. mucosus was $26 \cdot 3 \%$. Strain $\mathrm{HTCC} 2601^{\top}$ utilized a wide range of carbohydrates, including hexose monomers, sugar alcohols, organic acids and amino acids, as sole carbon sources. The DNA G + C content of strain $\mathrm{HTCC} 2601^{\top}$ was $65.4 \mathrm{~mol} \%$, and the predominant constituents of the cellular fatty acids were $18: 1 \omega 7 c(79 \cdot 7 \%)$ and 11 -methyl $18: 1 \omega 7 c(7 \cdot 5 \%)$. The strain differed from members of the closely related genera Salipiger and Palleronia in its morphological, biochemical and ecological characteristics. On the basis of the taxonomic data obtained in this study, a novel genus and species, Pelagibaca bermudensis gen. nov., sp. nov., is proposed; $\mathrm{HTCC} 2601^{\top}$ $\left(=\mathrm{KCTC} 12554^{\top}=\mathrm{JCM} 13377^{\top}\right)$ is the type strain of Pelagibaca bermudensis.
\end{abstract}

The Roseobacter clade (Giovannoni \& Rappé, 2000) in the order Rhodobacterales (Garrity et al., 2005) of the class Alphaproteobacteria is the second most abundant $16 \mathrm{~S}$ rRNA gene-clone type in marine environments, many members of which have recently been cultivated and characterized as representing novel genera and species (Cho \& Giovannoni, 2004; Martínez-Cánovas et al., 2004; Martínez-Checa et al., 2005; Van Trappen et al., 2004; Wagner-Döbler et al., $2003,2004)$. Intensive cultivation approaches using a highthroughput culturing method (Connon \& Giovannoni, 2002) resulted in the isolation of strain HTCC $2601^{\mathrm{T}}$, affiliated to the Roseobacter clade, from the western Sargasso Sea in the Atlantic Ocean; this isolate was subjected to taxonomic investigation. Polyphasic taxonomic analyses indicated that this marine isolate represents a novel genus and species.

The original liquid culture of strain $\operatorname{HTCC} 2601^{\mathrm{T}}$ was obtained using previously described high-throughput culturing approaches (Cho \& Giovannoni, 2003a). The strain was purified as single colonies on marine agar 2216 (MA; Difco) after incubation for 4 days at $25^{\circ} \mathrm{C}$, and was

Published online ahead of print on 2 December 2005 as DOI 10.1099/ ijs.0.64063-0.

The GenBank/EMBL/DDBJ accession number for the 16S rRNA gene sequence of strain $\mathrm{HTCC} 601^{\top}$ is $\mathrm{DQ} 178660$. stored as $10 \%(\mathrm{v} / \mathrm{v})$ glycerol suspensions in liquid nitrogen. Unless otherwise indicated, bacterial cultures were grown routinely on MA at $30^{\circ} \mathrm{C}$.

Nearly complete (1460 bp) 16S rRNA gene sequences of strain HTCC $2601^{\mathrm{T}}$ were obtained as described previously (Cho \& Giovannoni, 2003a) and used for phylogenetic analyses. Preliminary BLAST network searches in GenBank showed that, for strain HTCC $2601^{\mathrm{T}}$, the closest relative with a validly published name was Salipiger mucosus $\mathrm{A}^{\mathrm{T}}{ }^{\mathrm{T}}(96 \cdot 5 \%$ sequence similarity). To clarify the phylogenetic position of HTCC $2601^{\mathrm{T}}$, the $16 \mathrm{~S}$ rRNA gene sequence of the strain was carefully aligned using the ARB software package (Ludwig et al., 2004); only 1194 unambiguously aligned nucleotide positions were used for phylogenetic analyses in the ARB package and PAUP*, version 4.0 beta 10 (Swofford, 2002). Phylogenetic trees were generated by using neighbour joining (Saitou \& Nei, 1987) with the Kimura two-parameter model (Kimura, 1980), maximum parsimony with a heuristic search (Fitch, 1971) and maximum likelihood (Felsenstein, 1981). The robustness of phylogenetic trees generated by neighbour joining and maximum parsimony was evaluated by bootstrap analyses based on 1000 resamplings. In all of the phylogenetic trees, strain $\mathrm{HTCC} 2601^{\mathrm{T}}$ and the genera Salipiger and Palleronia formed a monophyletic clade, with $62-76 \%$ bootstrap support for a position within the order Rhodobacterales (Fig. 1). In spite of the high $16 \mathrm{~S}$ 


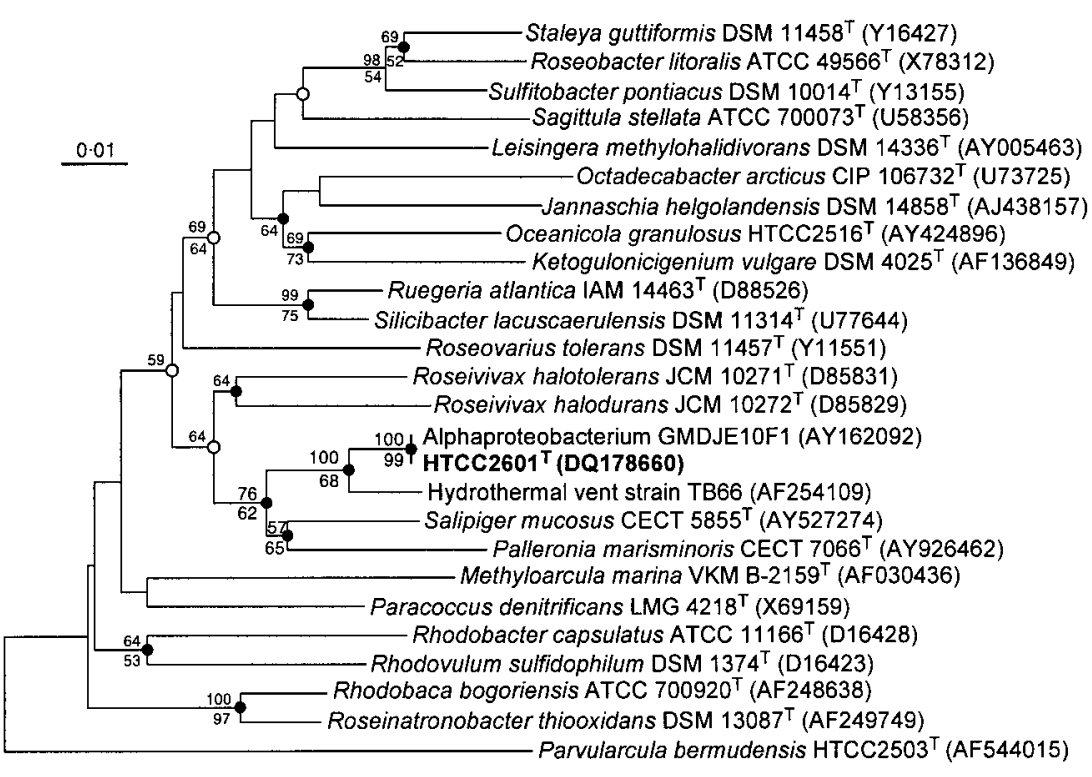

Fig. 1. Neighbour-joining phylogenetic tree, based on 16S rRNA gene sequences, showing relationships between strain $\mathrm{HTCC}_{2} 601^{\top}$ and representatives of the order Rhodobacterales. Bootstrap percentages (above $50 \%$ ) from both neighbour joining (above nodes) and maximum parsimony (below nodes) are shown. Filled and open circles at each node respectively indicate nodes recovered reproducibly by all treeing methods or by two treeing methods. Bar, 0.01 substitutions per nucleotide position.
rRNA gene sequence similarity $(96.5 \%)$ between strain HTCC $2601^{\mathrm{T}}$ and S. mucosus, the strain formed a separate subclade together with a Sargasso Sea bacterium, GMDJE10F1 (Zengler et al., 2002), with 99-100 \% bootstrap support within a clade containing the genera Salipiger and Palleronia (Fig. 1). The same branching-order pattern within the clade was always observed in all tree-inferring algorithms. These phylogenetic analyses suggested that strain HTCC $2601^{\mathrm{T}}$ represents a novel genus-level lineage within the Roseobacter clade of the order Rhodobacterales.

DNA-DNA hybridization was determined by dot-blot hybridization using the DIG High Prime DNA labelling and detection starter kit I (Roche Molecular Biochemicals) as described previously (Cho \& Giovannoni, 2003b). Strain HTCC $2601^{\mathrm{T}}$ showed $26 \cdot 3 \%$ DNA-DNA relatedness to $S$. mucosus, the closest species with a validly published name.

The DNA G + C content of strain HTCC $2601^{\mathrm{T}}$ was analysed by using HPLC (Mesbah et al., 1989) with a Platinum EPS reverse-phase $\mathrm{C} 18$ column. The respiratory quinones were analysed using reverse-phase HPLC (Komagata \& Suzuki, 1987). Cellular fatty acid methyl esters were prepared from a culture grown on MA at $30^{\circ} \mathrm{C}$ for 2 days, and analysed according to the instructions of the Microbial Identification System (MIDI). The DNA G $+\mathrm{C}$ content of strain HTCC $2601^{\mathrm{T}}$ was $65 \cdot 4 \pm 0 \cdot 4 \mathrm{~mol} \%$. The only respiratory quinone detected was Q-10. The major fatty acids in strain HTCC $2601^{\mathrm{T}}$ were $18: 1 \omega 7 c(79 \cdot 7 \%)$, 11-methyl $18: 1 \omega 7 c$ $(7 \cdot 5 \%)$ and $16: 0(4 \cdot 9 \%)$. Although the predominant fatty acid component of strains HTCC2601 ${ }^{\mathrm{T}}$, S. mucosus CECT $5855^{\mathrm{T}}$ and Palleronia marisminoris CECT $7066^{\mathrm{T}}$ was $18: 1 \omega 7 c$, these bacteria could be differentiated according to the proportions of several fatty acids, including 10:0 3-OH, 12:0 3-OH, 16:0 and 19:0 cyclo $\omega 8 c$ (Table 1).

Phenotypic characterizations were been performed as described previously (Cho \& Giovannoni, 2003a), using
MA as basal medium at $30^{\circ} \mathrm{C}$. Unless otherwise indicated, standard methods were employed for the phenotypic characterization of the strain, as described by Smibert \& Krieg (1994). A catalase test was performed by the addition of $3.0 \% \mathrm{H}_{2} \mathrm{O}_{2}$ to fresh colonies; oxidase activity was determined using Kovács' oxidase reagent. Other biochemical tests, including the determination of nitrate reduction, acid production from glucose and indole production, were carried out on API 20NE strips (bioMérieux) according to the manufacturer's instructions. Anaerobic growth was tested on MA at $30^{\circ} \mathrm{C}$ using both the Oxoid anaerobic system and the Merck Anaerocult mini C. Custom-made 48-well microplates containing 47 different carbon compounds (Cho \& Giovannoni, 2003a), each at a final concentration of $0 \cdot 2 \%$ $(\mathrm{w} / \mathrm{v}$ or $\mathrm{v} / \mathrm{v})$, were used to determine the utilization of various substrates as sole carbon sources; artificial sea water medium $\left(1^{-1}: 25 \cdot 0 \mathrm{~g} \mathrm{NaCl}, 1 \cdot 0 \mathrm{~g} \mathrm{MgCl}_{2} \cdot 6 \mathrm{H}_{2} \mathrm{O}, 5 \cdot 0 \mathrm{~g}\right.$ $\mathrm{MgSO}_{4} \cdot 7 \mathrm{H}_{2} \mathrm{O}, 0 \cdot 7 \mathrm{~g} \mathrm{KCl}, 0 \cdot 15 \mathrm{~g} \mathrm{CaCl}_{2} .2 \mathrm{H}_{2} \mathrm{O}, 0 \cdot 5 \mathrm{~g} \mathrm{NH}_{4} \mathrm{Cl}$, $0 \cdot 1 \mathrm{~g} \mathrm{KBr}, 0 \cdot 27 \mathrm{~g} \mathrm{KH}_{2} \mathrm{PO}_{4}, 0.04 \mathrm{~g} \mathrm{SrCl}_{2} .6 \mathrm{H}_{2} \mathrm{O}, 0.025 \mathrm{~g}$ $\mathrm{H}_{3} \mathrm{BO}_{3}$ ) was used for these tests. The ability of the strain to oxidize 95 different carbon sources was determined using Biolog SF-N2 microplates (Rüger \& Krambeck, 1994).

Detailed morphological, physiological and biochemical characteristics of strain HTCC $2601^{\mathrm{T}}$ are listed in the genus and species descriptions. The isolate was found to be a facultatively anaerobic, chemoheterotrophic, slightly halophilic, short rod-shaped bacterium that did not produce exopolysaccharides or poly- $\beta$-hydroxyalkanoate granules. No apparent differences in growth pattern were found between anaerobic cultures and aerobic cultures on MA in the Oxoid anaerobic system. Nitrate and nitrite were reduced on API 20NE strips. The strain utilized some simple carbohydrates, sugar alcohols, organic acids and amino acids as sole carbon sources. These phenotypic characteristics of strain HTCC $2601^{\mathrm{T}}$ clearly differentiate the strain from the most closely related species, S. mucosus and Palleronia 
Table 1. Characteristics that differentiate strain $\mathrm{HTCC} 2601^{\top}$ from members of the phylogenetically related genera Salipiger and Palleronia

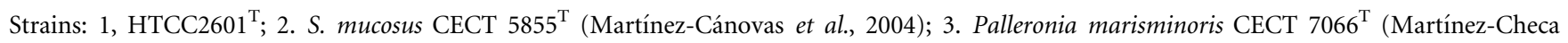
et al., 2005). +, Positive; -, negative; ND, not determined.

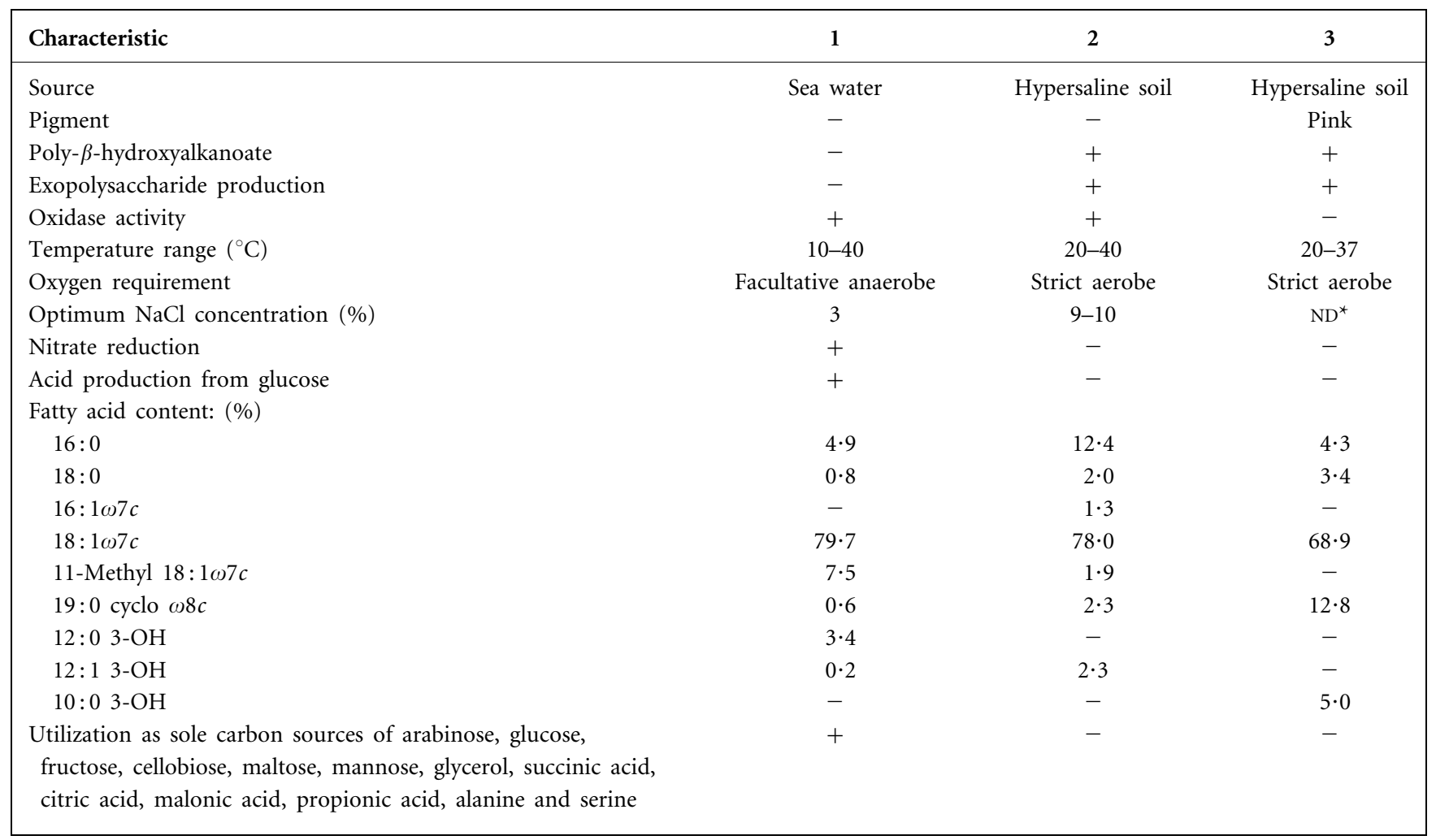

${ }^{*}$ The optimum $\mathrm{Na}^{+}$concentration for growth is $0.66 \mathrm{M}$.

marisminoris (Table 1). The genus Salipiger was proposed by Martínez-Cánovas et al. (2004) for a moderately halophlic, exopolysaccharide-producing, poly- $\beta$-hydroxyalkanoategranule-containing, strictly aerobic bacterium that formed a distinct clade within the Roseobacter clade. Additionally, the genus Palleronia was also proposed, by the same research group (Martínez-Checa et al., 2005), to be a moderately halophilic, exopolysaccharide-producing, strictly aerobic bacterium that is the phylogenetically closest neighbour with respect to the genus Salipiger. The important phenotypic characteristics that distinguish strain HTCC $2601^{\mathrm{T}}$ from members of the aforementioned two genera are the oxygen requirement for growth, the optimal $\mathrm{NaCl}$ concentration, the ability to reduce nitrate and the substrates utilized as sole carbon sources (Table 1). On the basis of these phenotypic traits, strain HTCC $2601^{\mathrm{T}}$ cannot be characterized as a member of any of the known genera within the order Rhodobacterales.

The polyphasic evidence, such as phenotypic data, fatty acid profiles, DNA-DNA hybridization and 16S rRNA gene phylogenetic analyses, demonstrated conclusively that strain HTCC $2601^{\mathrm{T}}$ belongs to a novel genus and species within the order Rhodobacterales, for which the names Pelagibaca gen. nov. and Pelagibaca bermudensis sp. nov. are proposed.

\section{Description of Pelagibaca gen. nov.}

Pelagibaca (Pe.la.gi.ba'ca. L. n. pelagus the open sea, the ocean; L. fem. n. baca berry, especially olive; N.L. fem. n. Pelagibaca an olive-shaped bacterium of the open ocean).

Cells are Gram-negative, non-motile, facultatively anaerobic, short rods (oval-shaped, $1 \cdot 2-2 \cdot 3 \mu \mathrm{m}$ long, $0 \cdot 6-1 \cdot 1 \mu \mathrm{m}$ wide) that multiply by binary fission. Carotenoid pigments and bacteriochlorophyll $a$ are not found. Do not produce exopolysaccharides or poly- $\beta$-hydroxyalkanoate. Nitrate and nitrite are reduced. Chemoheterotrophic and slightly halophilic; require $\mathrm{NaCl}$ for growth. Produce acids from glucose and utilize a variety of carbon compounds as sole carbon sources. The predominant fatty acids are $18: 1 \omega 7 c$ and 11-methyl $18: 1 \omega 7 c$. The only respiratory quinone detected is ubiquinone-10. The DNA $\mathrm{G}+\mathrm{C}$ content is $65.4 \mathrm{~mol} \%$. The genus is affiliated to the Roseobacter clade in the order Rhodobacterales and currently contains only one species, the type species Pelagibaca bermudensis. 


\section{Description of Pelagibaca bermudensis sp. nov.}

Pelagibaca bermudensis (ber.mu.den'sis. N.L. fem. adj. bermudensis from Bermuda).

In addition to having the traits reported for the genus, colonies on MA are circular, convex, cream-coloured, butyrous and $1 \cdot 2-2 \cdot 5 \mathrm{~mm}$ in diameter. Grows at $10-40{ }^{\circ} \mathrm{C}$, optimally at $30-33^{\circ} \mathrm{C}$, but not at 4 or $44^{\circ} \mathrm{C}$. Growth occurs at pH $5 \cdot 0-10 \cdot 5$ and $0 \cdot 25-15 \% \mathrm{NaCl}$, optimally at $\mathrm{pH} 8 \cdot 5$ and $3.0 \% \mathrm{NaCl}$. Catalase- and oxidase-positive. Does not produce indole. Arginine dihydrolase-negative. Urea, aesculin and gelatin are hydrolysed. $\beta$-Glucosidase activity is present. Utilizes DL-glyceraldehyde, D-arabinose, D-glucose, D-fructose, L-rhamnose, L-sorbose, sucrose, D-trehalose, D-cellobiose, D-maltose, D-mannose, D-melibiose, D-mannitol, D-sorbitol, methanol, glycerol, pyruvic acid, succinic acid, itaconic acid, citric acid, gluconic acid, malonic acid, propionic acid, L-glutamic acid, L-ornithine, L-proline, L-lysine, L-alanine, L-serine, L-leucine and L-arginine. D-Melezitose, myo-inositol, L-glutamic acid, D-ribose, D-xylose, D-galactose, $\beta$-lactose, D-raffinose, adonitol, ethanol, $\mathrm{N}$-acetyl-D-glucosamine, D-malic acid, formic acid, D-glucosamine, $\mathrm{L}$-isoleucine and glycine are not utilized as sole carbon sources (tested using custom-made, 48-well plate). In tests with Biolog SF-N2 microplates, the following substrates are utilized oxidatively: $\alpha$-cyclodextrin, Tweens 40 and 80 , adonitol, L-arabinose, D-arabitol, D-cellobiose, D-fructose, $\alpha$-D-glucose, maltose, D-mannitol, D-mannose, L-rhamnose, D-sorbitol, sucrose, D-trehalose, xylitol, pyruvic acid methyl ester, succinic acid monomethyl ester, acetic acid, citric acid, D-galacturonic acid, D-gluconic acid, $\gamma$-hydroxybutyric acid, $\alpha$-ketobutyric acid, $\alpha$-ketoglutaric acid, DL-lactic acid, malonic acid, propionic acid, succinic acid, bromosuccinic acid, succinamic acid, glucuronamide, L-alaninamide, L-alanine, L-glutamic acid, L-leucine, L-ornithine, L-phenylalanine, L-proline, L-serine, L-threonine, 2,3-butanediol, glycerol, and $\alpha$-DL-glycerol phosphate. Susceptible to chloramphenicol $(25 \mu \mathrm{g})$, nalidixic acid $(25 \mu \mathrm{g})$, carbenicillin $(25 \mu \mathrm{g})$, tetracycline $(30 \mu \mathrm{g})$, ampicillin $(10 \mu \mathrm{g})$, puromycin $(25 \mu \mathrm{g})$, erythromycin $(15 \mu \mathrm{g})$, rifampicin $(50 \mu \mathrm{g})$, benzylpenicillin $(100 \mathrm{U})$ and gentamicin $(10 \mu \mathrm{g})$, but resistant to kanamycin $(30 \mu \mathrm{g})$, vancomycin $(30 \mu \mathrm{g})$ and cycloheximide $(50 \mu \mathrm{g})$. The cellular fatty acids are composed of $18: 1 \omega 7 c(79.7 \%), 11$ methyl $18: 1 \omega 7 c(7 \cdot 5 \%), 16: 0(4 \cdot 9 \%), 12: 03-\mathrm{OH}(3 \cdot 4 \%)$, $18: 0(0 \cdot 8 \%), 19: 0$ cyclo $\omega 8 c(0 \cdot 6 \%), 18: 1 \omega 9 c(0 \cdot 6 \%), 10: 0$ $3-\mathrm{OH}(0 \cdot 4 \%), 12: 13-\mathrm{OH}(0 \cdot 2 \%)$ and $17: 0(0 \cdot 2 \%)$.

The type strain, HTCC $2601^{\mathrm{T}}\left(=\mathrm{KCTC} 12554^{\mathrm{T}}=\mathrm{JCM}\right.$ $13377^{\mathrm{T}}$ ), was isolated from the Bermuda Atlantic Time Series Station in the western Sargasso Sea, Atlantic Ocean.

\section{Acknowledgements}

We are grateful to the crew of the R/V Weatherbird II for their assistance in the collection of sea-water samples and to Diversa Corp. for support with the high-throughput culturing experiment. We would like to thank Dr Jean Euzéby for his recommendations regarding the etymology. This study was supported by the 21C Frontier Program of
Microbial Genomics and Applications (grant MG05-0102-1-0) from the Ministry of Science and Technology, Republic of Korea, and by the Gordon and Betty Moore Foundation.

\section{References}

Cho, J.-C. \& Giovannoni, S. J. (2003a). Parvularcula bermudensis gen. nov., sp. nov., a marine bacterium that forms a deep branch in the $\alpha$-Proteobacteria. Int J Syst Evol Microbiol 53, 1031-1036.

Cho, J.-C. \& Giovannoni, S. J. (2003b). Fulvimarina pelagi gen. nov., sp. nov., a marine bacterium that forms a deep evolutionary lineage of descent in the order 'Rhizobiales'. Int J Syst Evol Microbiol 53, 1853-1859.

Cho, J.-C. \& Giovannoni, S. J. (2004). Oceanicola granulosus gen. nov., sp. nov. and Oceanicola batsensis sp. nov., poly- $\beta$-hydroxybutyrateproducing marine bacteria in the order 'Rhodobacterales'. Int J Syst Evol Microbiol 54, 1129-1136.

Connon, S. A. \& Giovannoni, S. J. (2002). High-throughput methods for culturing microorganisms in very-low-nutrient media yield diverse new marine isolates. Appl Environ Microbiol 68, 3878-3885.

Felsenstein, J. (1981). Evolutionary trees from DNA sequences: a maximum likelihood approach. J Mol Evol 17, 368-376.

Fitch, W. M. (1971). Toward defining the course of evolution: minimum change for a specific tree topology. Syst Zool 20, 406-416.

Garrity, G. M., Bell, J. A. \& Lilburn, T. (2005). Order III. Rhodobacterales ord. nov. In Bergey's Manual of Systematic Bacteriology, 2nd edn, vol. 2, p. 161. Edited by D. J. Brenner, N. R. Krieg, J. T. Staley \& G. M. Garrity. New York: Springer.

Giovannoni, S. \& Rappé, M. (2000). Evolution, diversity and molecular ecology of marine prokaryotes. In Microbial Ecology of the Oceans, pp. 47-84. Edited by D. L. Kirchman. New York: Wiley.

Kimura, M. (1980). A simple method for estimating evolutionary rates of base substitutions through comparative studies of nucleotide sequences. J Mol Evol 16, 111-120.

Komagata, K. \& Suzuki, K. (1987). Lipids and cell-wall analysis in bacterial systematics. Methods Microbiol 19, 161-203.

Ludwig, W., Strunk, O., Westram, R. \& 29 other authors (2004). ARB: a software environment for sequence data. Nucleic Acids Res 32, 1363-1371.

Martínez-Cánovas, M. J., Quesada, E., Martínez-Checa, F., del Moral, A. \& Bejar, V. (2004). Salipiger mucescens gen. nov., sp. nov., a moderately halophilic, exopolysaccharide-producing bacterium isolated from hypersaline soil, belonging to the $\alpha$-Proteobacteria. Int J Syst Evol Microbiol 54, 1735-1740.

Martínez-Checa, F., Quesada, E., Martínez-Cánovas, M. J., Llamas, I. \& Bejar, V. (2005). Palleronia marisminoris gen. nov., sp. nov., a moderately halophilic, exopolysaccharide-producing bacterium belonging to the 'Alphaproteobacteria', isolated from a saline soil. Int J Syst Evol Microbiol 55, 2525-2530.

Mesbah, M., Premachandran, U. \& Whitman, W. B. (1989). Precise measurement of the $\mathrm{G}+\mathrm{C}$ content of deoxyribonucleic acid by high-performance liquid chromatography. Int J Syst Bacteriol 39, 159-167.

Rüger, H.-J. \& Krambeck, H.-J. (1994). Evaluation of the BIOLOG substrate metabolism system for classification of marine bacteria. Syst Appl Microbiol 17, 281-288.

Saitou, N. \& Nei, M. (1987). The neighbor-joining method: a new method for reconstructing phylogenetic trees. Mol Biol Evol 4, 406-425. 
Smibert, R. M. \& Krieg, N. R. (1994). Phenotypic characterization. In Methods for General and Molecular Microbiology, pp. 611-654. Edited by P. Gerhardt, R. G. E. Murray, W. A. Wood \& N. R. Krieg. Washington, DC: American Society for Microbiology.

Swofford, D. (2002). PAUP ${ }^{\star}$. Phylogenetic Analysis Using Parsimony (and other methods). Sunderland, MA: Sinauer Associates.

Van Trappen, S., Mergaert, J. \& Swings, J. (2004). Loktanella salsilacus gen. nov., sp. nov., Loktanella fryxellensis sp. nov. and Loktanella vestfoldensis sp. nov., new members of the Rhodobacter group, isolated from microbial mats in Antarctic lakes. Int J Syst Evol Microbiol 54, 1263-1269.
Wagner-Döbler, I., Rheims, H., Felske, A., Pukall, R. \& Tindall, B. J. (2003). Jannaschia helgolandensis gen. nov., sp. nov., a novel abundant member of the marine Roseobacter clade from the North Sea. Int J Syst Evol Microbiol 53, 731-738.

Wagner-Döbler, I., Rheims, H., Felske, A., El-Ghezal, A., FladeSchroder, D., Laatsch, H., Lang, S., Pukall, R. \& Tindall, B. J. (2004). Oceanibulbus indolifex gen. nov., sp. nov., a North Sea alphaproteobacterium that produces bioactive metabolites. Int J Syst Evol Microbiol 54, 1177-1184.

Zengler, K., Toledo, G., Rappe, M., Elkins, J., Mathur, E. J., Short, J. M. \& Keller, M. (2002). Cultivating the uncultured. Proc Natl Acad Sci U S A 99, 15681-15686. 